\title{
Monstrous Melancholy: Ficino and the Physiological Causes of Atheism
}

\section{Citation}

Hankins, James. Forthcoming. Monstrous melancholy: Ficino and the physiological causes of atheism. In Laus Platonici Philosophi: Marsilio Ficino and his Influence, ed. Stephen Clucas, Peter J. Forshaw, and Valery Rees. Leiden: E. J. Brill.

\section{Permanent link}

http://nrs.harvard.edu/urn-3:HUL.InstRepos:2941448

\section{Terms of Use}

This article was downloaded from Harvard University's DASH repository, and is made available under the terms and conditions applicable to Other Posted Material, as set forth at http:// nrs.harvard.edu/urn-3:HUL.InstRepos:dash.current.terms-of-use\#LAA

\section{Share Your Story}

The Harvard community has made this article openly available.

Please share how this access benefits you. Submit a story.

Accessibility 


\title{
Monstrous Melancholy: \\ Ficino and the Physiological Causes of Atheism
}

\author{
James Hankins ${ }^{1}$
}

The final section of Robert Burton's Anatomy of Melancholy (1621) contains a remarkable and - according to Burton himself - largely original treatment of a condition that Burton labels 'religious melancholy'. As analyzed by Burton, religious melancholy is of two species, both extremes in relation to a virtuous mean of 'true religion'. The excess of religion is described as superstition, irrational religious enthusiasm or sanctimoniousness.

\footnotetext{
Not that there is any excesse of divine worship or love of God, that cannot be, we cannot love God too much [...]. But because we doe aliud agere, zealous without knowledge, and too sollicitous about that which is not necessary, busying our selves about impertinent, needlesse, idle and vaine ceremonies [...]. Some of us againe are too deare, as we think, more divine and sanctified then others, of a better mettle, greater guifts, and, with that proud Pharisie, contemne others in respect of our selves. [...] Of this number are all superstitious Idolators, Ethnickes [i.e. pagans], Mahometans, Jewes, Hereticks, Enthusiasts, Divinators, Prophets, Sectaries, and Schismaticks. ${ }^{3}$
}

At the other extreme, marked by defect or lack of religion, lie the impious of various descriptions:

In the other extreame or in defect, march those impious Epicures, Libertines, Atheists, Hypocrites, Infidels, worldly, secure [i.e. lacking concern for their souls], impenitent, unthankfull, and carnall minded men, that attribute all to naturall causes, that wil acknowledge no supreame power; that have cauterized consciences, or live in a reprobate sense: or such desperate persons as are too distrustfull of His mercies. ${ }^{4}$

After dealing at length with the excess of religion (3.4.1.1-5), Burton returns again to its defect (3.4.2.1), giving a second list of those who display the sickness. 
In that other extreame, or defect of this love of God, knowledge, faith, feare, hope, \&c. are such as erre both in doctrine and manners, Sadduces, Herodians, Libertines, polititians [i.e. politiques in the late Renaissance sense], all manner of Atheists, Epicures, Infidels, that are secure, in a reprobate sense [i.e. in a state of damnation], feare not God at all, and such are too distrustfull and timorous, as desperate persons be: That grand sinne of Atheisme or impiety, Melancthon calls it, monstrosam melancholiam, monstrous melancholy. ${ }^{5}$

From a modern point of view it seems unaccountable to lump together under a single rubric persons indifferent to religion, scoffers, persons who defy normal standards of morality, statesmen who pursue power rather than principle, hypocrites, philosophical atheists, and the despairing - persons who are religious but doubt of their own salvation. ${ }^{6}$ Even odder from our point of view is the distinction Burton introduces between what one might call hard and soft atheism. Hard atheism is espoused by philosophers who attribute all to natural causes and 'hold all religion a fiction'; such an atheist will deny he has a religion but will call himself 'a philosopher, a Galenist, ${ }^{8}$ an Averroist, and with Rablais a phisitian, a Peripateticke, an Epicure [i.e. Epicurean].' Burton's examples are Averroes, Giordano Bruno (infelix Brunus), Machiavelli and Giulio Cesare Vanini, as well as ancient philosophers such as Diagoras, Demonax, Epicurus, Pliny, Lucian and Lucretius. But there is also a 'milder sort' of 'Atheisticall spirits' that 'professe religion, but timide et haesitanter, tempted thereunto out of that horrible consideration of diversity of Religions, which are, and have beene in the world'. 'Burton gives as his example of the latter Tommaso Campanella. These seemed to be the sort of religious thinker that would later be classified as 'Deists'. ${ }^{10}$ Burton clearly understands atheism in the broader, early modern sense of the word that includes not only persons who disbelieve in the existence of God but persons who reject the dogmas and moral tenets of traditional Christianity, either mainstream Protestantism or Roman Catholicism. ${ }^{11}$ It is this broader sense of atheism that will be employed in the rest of this essay.

Burton's taxonomy only makes sense when we realize that he regards 'true religion' as a state of physical as well as mental health; or to speak more accurately, that there is a two-way causal relationship between mental and bodily states. Religion is natural to man and religious belief is sustained in most people by a balanced tempering of humors in the body. Atheism is 'caused' by wrong beliefs or diabolic activity but it is also contracted, sustained and exacerbated by the presence of an abnormal bodily state known as melancholia. In 
melancholics the blood dries up and alters the body's temperament, its humoral mixture, so that it is dominated by black bile or choler. This inclines a person to fear and despair and makes it harder to love and believe. True religion is to love and fear God in the appropriate measure, but that mean is hard to maintain if our bodily states do not support our animal spirits. Everyone can have moments of doubt but 'corrupt affections', if indulged, can cause 'this brutish passion' to poison our mental habits permanently so that we persist in the unnatural state of unbelief.

The devil is the 'principle agent and procurer' of atheism, but he does this ordinarily by exploiting the possibilities offered by the melancholy humor:

His [the devil's] ordinary engine by which he produceth this effect [despair, doubt and atheism] is the melancholy humour it selfe, which is Balneum Diaboli, the Divel's bath; and as in Saul, ${ }^{12}$ those evill spirits get in as it were, and take possession of us. Blacke choler [the melancholy humor] is a shooing horne, a bait to allure them, in so much that many writers make melancholy an ordinary cause, and a symptome of despaire, for that such men are most apt, by reason of their ill disposed temper, to distrust, feare, griefe, mistake [i.e., incur doctrinal error], and amplifie whatsoever they preposterously conceave or falsely apprehend. ${ }^{13}$

As a concave glasse reflects solid bodies, a [brain troubled by melancholy] for want of sleepe, nutriment and by reason of that agitation of spirits to which Hercules de Saxonia attributes all Symptomes almost, may reflect and shew prodigious shapes, as our vaine fear and crased phantasie shall suggest and faigne. ${ }^{14}$

To cure the soul-sickness of atheism, Burton stipulates that both verbal cures, i.e., persuasion and argument, and medical cures are appropriate and valid. The former should be applied by 'divines', the latter by doctors. It is worth noting that professional men of religion here take the place of philosophers, who in antiquity would have been charged with the verbal part of therapeia psyches or the care of souls.

Bellovacus cured a Monke by altering his habit, and course of life: Plater many by Physicke alone. But for the most parte they [the two therapies] must concurre; and they take a wrong course that thinke to overcome this ferall passion by sole Physicke; and they are as much out, that thinke to worke this effect by good advice alone, though both be forcible in themselves, yet vis unita fortior, they must goe hand in hand to this disease: Alterius sic altera poscit opem. For 
Physicke, the like course is to be taken with this as in other melancholy, diet, aire, exercise, all those passions and perturbations of the minde, \&c. are to be rectified by the same meanes. ${ }^{15}$

Burton then goes on to present therapies of both kinds, though he spends most of his effort on talking cures, which he collects and digests out of a variety of religious literature, including sermons, systematic treatises and apologetic literature. His emphasis on verbal cures does not reflect low esteem for medical cures. It is rather that he regards medical cures for religious melancholy as already well known and widely available, whereas talking cures 'are not to all parties at hand'; his digest of 'comfortable speeches, exhortations, arguments, advice' is compiled at the specific request of friends, and was in fact added after the first edition of the work. ${ }^{16}$ But he explicitly states that 'there bee those that prescribe physicke in such cases, 'tis God's instrument, and not unfit'. ${ }^{17}$ He recommends a number of authors who offer purely medical treatments for melancholy, which include the use of 'Amulets, hearbs, and pretious stones, which have marvelous vertues all'; music ('so Saul was helped by Davids harp'), fires, lights, odors, perfumes and suffumigations.

A reading of Burton on religious melancholy makes it plain that he is part of a tradition of thought that is already well established. Even though he claims his taxonomy of religious melancholy is original, the sources Burton cites show that European doctors and divines had been discussing the physiological causes and cures of abnormal mental states, including unbelief, irreligion and despair of salvation, for at least a century. ${ }^{18}$ Burton cites dozens of authorities from Philip Melanchthon and Levinus Lemnius to Felix Platter and Ercole Sassonia who discuss the subject. He does not, however, cite one even earlier author, an author who to my knowledge is the earliest author to discuss the physiological basis of religious despair and unbelief and to offer medical cures for it: Marsilio Ficino. ${ }^{19}$

It may perhaps surprise the reader to identify Ficino as the fountainhead of Renaissance discussions of the physiological causes of atheism. Ficino was a Platonist who took Plotinus as his most important guide to the dialogues, and it is one of the hallmarks of Plotinian metaphysics that higher, immaterial things cannot be in potency to material things; causal relationships between body and soul are a one-way street. The soul controls the body, it is 
'in' the soul, and not vice-versa. Soul remains itself untouched by the body; associated with it but not in union with it. Soul controls body via an eidolon or ellampsis, an image or irradiation of itself projected into the body; it is that which experiences bodily passions. ${ }^{20}$ This is a view explicitly endorsed by Ficino in a number of places. ${ }^{21}$ It was not necessarily Plato's own view, of course; one has only to think of the famous passage in Plato's Timaeus where he describes the turmoil inflicted on the soul by its being plunged into the body - its perfect circular motions perverted by the subrational bombardment of rectilinear motion - to realize that there is plenty of material in Plato to underwrite a more physicalist view of soul-body interactionism. ${ }^{22}$ Nevertheless, when considering the history of the soul-body relation in Western philosophy it is normal to regard Plato as the chief opponent of more naturalistic accounts of psychosomatic relations. Plato was strongly associated with the view that the health of the body is dependent on the health of the soul, or sophrosyne (see especially Charmides 156d), whereas it was the Epicureans and some Stoics who were more likely to embrace the view that there is continuous interaction between states of the body and states of soul.

But Ficino was also a follower of Galen in medicine. In De vita (1489), his book on magic, Ficino says that the twin inspirations of his life were his father, the doctor Dietifeci Fecino, and Cosimo de'Medici: 'the former commended me to Galen, the doctor and Platonist; the latter to the divine Plato. Both alike destined Marsilio to be a doctor, Galen being a doctor of bodies and Plato of souls. ${ }^{23}$ And while it is true that Galen called himself a Platonist and Ficino regarded him as such, ${ }^{24}$ he could hardly be called an orthodox Platonist (whatever that might mean). Galen always refused to offer an opinion about the immortality of the soul or even a view about its somatic or asomatic character. He would not take a position on transmigration, on the number of the soul's parts or functions, and on other key Platonic psychological doctrines. His view of soul-body transactions is deeply colored by Epicurean and Stoic materialism and physicalism. ${ }^{25}$ As Heinrich von Staden writes, 'Th[e] interactive relation between humoral blend or temperament and the soul's capacities is a central feature of Galen's view of the body-soul relation. ${ }^{26}$ Even more remarkably, in the treatise Quod animi mores corporis temperamenta sequantur ('That psychic behavior follows bodily temperaments') he argues (as the title suggests), that the enkrasia or good tempering of the body somehow contributes to moral excellence of soul. He goes so far as to claim that there is a dependence or 'servitude' (doulouein) of the soul on bodily states, though he rejects a more rigorous 
physical determinism of the Stoic type. Indeed, certain diseases of soul such as delirium, melancholy and lethargy are clearly physical in origin and are conceived of as the result of humoral imbalances of various kinds. This being the case, it is natural that the soul can be affected by diet, environment, drugs, physical activity and other non-psychic causes. On the modern issue of whether mental disease should be treated by 'talking cures', psychotherapy, or by drugs and other forms of physiological intervention, Galen comes down squarely on the side of the latter. Like other figures in the Hippocratic tradition, Galen did not draw on the psychotherapeutic doctrine of Plato and did not make wide use of 'verbal catharsis' in his treatment of mental illnesses. ${ }^{27}$

So despite Ficino's Neoplatonism, we find in his writings a Galenic readiness to recognize the influence of the body on the soul. This theme has been explored in the large literature on Ficino's magical doctrine in De vita, as has Ficino's doctrine of the psychic disease of melancholy, especially as it relates to the notion of genius. ${ }^{28}$ But no modern scholar to my knowledge has noted that Ficino also connected religious health with the health of the body, and religious diseases such as doubt, impiety and atheism with bodily disorders. ${ }^{29}$ Nor does the literature on Burton or religious melancholy in early modern Europe recognize Ficino's role in the tradition. ${ }^{30}$ The absence of any discussion of Ficino on religious melancholy is easy enough to explain. Ficino's remarks on this subject are not treated where one would expect to find them, in De vita, but hidden deep in the recesses of the Platonic Theology (1482), Ficino's difficult 18-book work of metaphysics where he defends the immortality of the soul using materials from the ancient Platonic tradition. Ficino's treatment of the theme of religious melancholia leading to atheism indeed casts De vita in a rather different light and may provide a key to Ficino's motivation in writing it. We shall return to this point later on.

Ficino's treatment of religious melancholia occurs in the third part of his Theology where he is replying to the objections of various philosophical doubters about personal immortality. ${ }^{31}$ Book 14 is devoted to answering Lucretius and the Lucretiani, who argue that religion itself is a sickness of soul. If I am not mistaken, it is the first example in the history of Christian apologetics where a theologian has devoted serious thought to countering Lucretius's attack on religion in De rerum natura. ${ }^{32}$ Defending religion in general, rather than the Christian religion in particular, forces Ficino to consider religion itself as a category of analysis, and Ficino's treatment thus becomes an important milestone in what has been called 'the objectification of religion', the study of religion as an anthropological 
phenomenon. And if Alison Brown is correct that Lucretianism is a live option in late fifteenth- and early sixteenth-century Florence, Ficino's engagement with Lucretius can be understood as a dialogue with contemporary Lucretians. It is hard, for obvious reasons, to identify individual Lucretians in the Quattrocento, ${ }^{33}$ but we do know of one young man in mid-fifteenth-century Florence who was powerfully attracted to Lucretius, namely Ficino himself. Ficino as a young man in the later 1450 s wrote commentariola on De rerum natura which he later consigned to the flames, regarding them as products of his frivolous youth. We also know of one occasion in his youth when Ficino referred to Lucretius as 'Lucretius ille noster Epicureorum philosophorum clarissimus'. It seems likely that Lucretian philosophy played a role in Ficino's youthful religious crisis, ${ }^{34}$ and that the Florentine philosopher's passionate rejection of Lucretius in the Platonic Theology was connected with his return to orthodoxy and his lifelong commitment to reconciling Platonic philosophy with Christianity. $\frac{35}{-}$ In fact, as the present writer has argued elsewhere, Ficino's whole interpretation of the Christian religion is shaped by the need to make it impregnable to the Lucretian critique of religion. ${ }^{36}$

In Ficino's view, Lucretius's aetiology of religion is reducible to three heads. Religion can be understood as a disease (corruptio complexionis), as a political imposture, or as a natural phenomenon traceable to astrological causes (14.10.1). It has nothing to do with the real gods, who live a life apart from the world and have no concern for us; there is no such thing as Providence. Religion exploits the fears natural to the human condition and makes us miserable by exaggerating them and perverting them; this emotional manipulation serves the interests of priests and politicians but prevents mankind from finding the true way to happiness, which only Epicurus among the philosophers found. The corruption of our souls by religion leads us to perform terrible acts, such as the sacrifice of Iphigenia. Tantum religio potuit suadere malorum. Doctrines such as the immortality of the soul are designed to terrify us into good behavior but true philosophy shows they are false. Recognition of this fact leads to the only kind of happiness appropriate to the human animal, the tranquility that comes from being free of false opinions and the passions they enflame. Most men are condemned to suffer from the illusions of religion but a few philosophical spirits can escape the misery of mankind and observe its sufferings from a loftier perspective, from the sapientum templa serena, like a man, safe on shore, watching a ship foundering upon the sea. 
Ficino's defense of religion turns Lucretius's aetiology and pathology of religion on its head. The specific excellence of the human species, the faculty that perfects it and sets it apart from the beasts, is not its ability to make objects, to govern itself, to communicate in words or to reason. This is what various philosophers in the past have said but they are wrong. The true excellence and perfection peculiar to man qua man is 'contemplation of the divine' (contemplatio divinorum). Worship is as natural to man as neighing to horses or barking to dogs. A man without a religious sense is a monster. This sets up what is for Ficino the central argument in both the Platonic Theology and De christiana religione-placed prominently at the beginning of both texts ${ }^{37}$ - for why there has to be a true religion amid all the human delusions and superstitions about the divine.

\footnotetext{
Rursus, si homo animalium mortalium perfectissimus est, in quantum homo, ob eam praecipue dotem est omnium perfectissimus quam inter haec habet ipse propriam, ceteris animalibus non communem, ea religio est; per religionem igitur est perfectissimus. Si religio esset inanis, per eam rursus homo omnium esset imperfectissimus, quoniam per eam dementissimus esset atque miserrimus.
}

\footnotetext{
Again, if man qua man is the most perfect of mortal animals, he is most perfect of all especially on account of that gift, religion, which belongs to him alone and is not shared with other animals; therefore he is most perfect because of religion. Then again if religion were empty, man would be the most imperfect creature of all, since through it he would be made utterly demented and miserable. ${ }^{38}$
}

Lucretius would be right on the hypothesis that there was no true religion, but (as Ficino sets out to prove in De christiana religione) there is such a religion, the Christian religion, so Lucretius's argument fails. Ficino believes it is absurd and contradictory to suppose man, the highest of animals, is also the most miserable animal, the least capable of happiness. Absurd since the higher on the chain of being any substance is, the closer it will be to the source of beatitude. Contradictory since the same faculty, the religious sense, that makes man most blessed on the hypothesis that religion is true cannot be the same one that makes him most miserable on the hypothesis that it is false. 'There exists therefore true religion' ${ }^{39}$ Since man's lot is miserable unless there is hope of another life, the soul must be immortal. ${ }^{40}$ Moreover, if we accept (as Lucretius does not) that there is some intelligent order in the universe, a providence or purpose in creation, then the universality of the religious sense has 
to have some function tending to the perfection or happiness of the creature who possesses it. All men are led to natural piety via (a) a 'natural sagacity' infused in them by Providence, (b) the argument from design, and (c) prophecy and miracles. All men worship God for the sake of a future life, says Ficino, and this can be regarded as a kind of prophecy made by the species as a whole, therefore true, for 'prophesying that comes from an entire animal species is true'. 'Many reptiles slithering out of the earth's bosom when the sun rises portend fog. Numerous flocks of rooks in the evening flying from a certain region of the sky foretell winds.' Just so, the fact that all humanity believes in a future life shows that there is one. ${ }^{41}$

Ficino's naturalistic argument for the existence of true religion (or a true religion) therefore requires him to produce an equally naturalistic explanation for why some men do not believe in any religion at all, and it is in this context that he puts forth his account of 'monstrous melancholy'. He might in theory have appealed to a special reprobation of God, but this would have undercut his broader commitment to metaphysical optimism. ${ }^{42}$ It would also have been a circulus in arguendo if used as an argument against atheism. He does appeal briefly, in a single sentence, to the activity of demons at the end of his long naturalistic account of the physiological origins of impiety. ${ }^{43}$ But since he is in principle writing to convince the ingeniosi and doubters about the truth of religion, he naturally wants to emphasize the scientific explanation of impiety. This explanation he sets out in Chapter 10 of Book XIV ( $\left.\iint 1-8\right)$.

Broadly speaking, Ficino's argument rests on the orthodox Aristotelian assumption that any phenomena occurring in the great majority of cases and in the more perfect cases should count as natural and veridical, while phenomena that appear in very few cases or in the case of sick people should be considered monstrosities (or aberrations as we might say) and misleading, not to be taken as evidence in constructing a definition. ${ }^{44}$ Most men who worship God in general exhibit the normal, sanguinary balance of humors while the tiny minority who do not generally have depraved complexions (or temperaments, i.e., humoral mixtures). The converse is not true: not all those with diseased temperaments are doubters; far from it. Nor is it true that all clever and wise men are doubters. Ficino cites evidence from ancient religion both Christian and pagan to prove the opposite:

The Magi of the Persians, the Egyptian priests, the Hebrew prophets, the Orphic, Pythagorean, and Platonic philosophers, and the ancient theologians of the Christians have 
demonstrated this. It is beyond dispute that all these excel in marvelous wisdom and incomparable sanctity. In discussing prayer, Porphyry says that in all nations the men who excel most in the study of wisdom devote themselves to prayers: among the Indians such were the Brahmans, among the Persians the Magi, and the like among the Greeks and Chaldaeans. This is what Porphyry says. ${ }^{45}$ And one must not suppose that these men, who confirmed their life's sanctity both with everlasting works and at their own mortal peril, were just pretending. There have been very many other most learned philosophers, barbarian, Greek, and Latin, who, though they have not attained the same purity of life as those I recalled earlier, have led nonetheless honorable and upright lives and never hesitated to favor religious observances. It is possible that some of them pretended to some degree, yet I do not believe that all pretended or that all were wanting in religion among those who did pretend. For it is difficult to cast our nature entirely aside. It is reported that Diagoras, Dicaearchus, Epicurus, and Lucretius were impious beyond others, but that occasionally they too were compelled by nature to assent to sundry religious observances, as their books testify. But just as they raised various objections against religion without being punished, so, if the impious were in the majority, many other philosophers too would have openly spewed out the poison of their godlessness. But not to admit, as many do, one or other religious cult is not the same as rejecting all religion entirely. Very few have attempted the latter and they have done so indeed by voicing doubts rather than rooted convictions. ${ }^{46}$

It is interesting that Ficino answers preemptively the obvious objection that wise and clever men who were religious might have been pretending to be so out of fear of punishment-a consideration with obvious contemporary relevance.

But Ficino still has to explain how, in at least a few documented cases, clever and learned men have doubted that any religions were true. He gives us two sorts of explanation. The first emphasizes the problems that arise when young men are introduced to religious truth without the appropriate mental and moral formation. In these cases skeptical youths are enjoined to be patient and trust that they will understand deeper truths when they are older and less passionate and have a more holistic sense of God, man and nature. If they are taught the disciplines in the proper order they will be much less likely to fall into irreligion and skepticism. ${ }^{47}$ The second explanation, which is what concerns us here, blames atheism on the influence of the disease of melancholy (as distinct from the melancholic humor as such), a disease to which intellectuals are particularly subject. 
Add to this that many men who excel in some art are either natural melancholics, as Heraclitus, Aristotle, and Chrysippus were, or they become such, as Democritus, Zeno of Citium, Avempace the Arab, and Averroes turned out to be. ${ }^{48}$ This melancholic humor is cold, dry, and black, three qualities that are opposite to the three wherein life's vigor consists-opposite, that is, to heat, to wetness, and to the transparent spirit. Such a humor, being the contrary of life, banishes life's hope and injects doubt, the enemy of life, into the rational soul. Consequently melancholics sometimes doubt and despair of the soul's immortality. Avempace writes that this happened to him. They doubt, not because they excel in intellectual ability and doctrine, but because the earthly humor makes them doubtful and cowardly. ${ }^{49}$

Ficino hastens to point out that the melancholic temperament is not in itself a guarantee of impiety: so long as men are properly educated and take care of their bodies, they 'easily put doubts aside and follow their natural instinct for religion'. Pythagoras, Socrates, Plato, Varro and Apollonius of Tyana are said to be melancholics who overcame their natural disposition and even 'experience[d] the greatest hope'. So the fact that many intelligent men deny the immortality of the soul should be dismissed as the effects of disease, in many cases exacerbated by astrological causes:

Moreover, those in whose birth Saturn and Mercury most dominate are often more acute. For these planets invite us to contemplation because they concentrate the spirits on interior things. If they are moving regularly forwards and are best disposed, they enhance the intelligence and do not diminish religion. But if they are retrograde and not best disposed, they render a man extremely fearful and despairing at every turn, their earthy quality being insufficiently tempered by the aspect of the other planets; accordingly he is doubtful and mistrusting not only in religion but in other matters as well. ${ }^{50}$

This means that we should not 'put full trust in that opinion which results either from a melancholic bent, one sick and contrary in a way to life, or from an inappropriate and harmful position of the stars.' Melancholics under the influence of Saturn are no more to be trusted in matters of religion than sick people are to be trusted to judge the taste of wine. We should rather trust the judgement of men who are healthy and sanguine in temperament:

But in man the complexion I call healthy and natural is the perfectly tempered sanguine one. The sanguine is airy and consists of heat and vital wetness; and, being tempered, it is like the heavens and does not cloud our ability to judge the truth. Such for the most part are the 
human complexions best suited to prudence and having a balanced personality. It is true they do not give us religion (for religion is poured divinely into our mind, since it orders us to neglect all else for the sake of things divine); but they do not impede religion in any way, and they do not inject groundless doubts into the rational soul. ${ }^{51}$

As the last sentence shows, Ficino is careful to separate the causes of religion and irreligion from the physical predispositions to the same. He is equally careful to say that the predominance of the melancholic humor as such does not predispose to atheism so much as the melancholic's persistance in the habit of unbelief, in 'depraved habits and customs', that 'leads mankind away from religion_(14.10.8).'

For men who are overly curious in any discipline because of their brain's excessive agitation usually become in a way insane, their brain having dried out. [...] No wonder therefore if men who are overly curious about the arts are sometimes clearly mad with regard to religious and other matters: their insanity is made manifest both by their extremely flippant behavior and by the wholly ridiculous and self-contradictory opinions they hold about many matters. ${ }^{52}$

It is therefore not religion but Lucretian impiety that is caused by 'corruption of the complexion'.

It would be natural to suppose, given Ficino's understanding of the humoral and astrological predispositions to atheism, that his De vita, published about seven years after the Platonic Theology, was written at least in part with the aim of fighting the physiological causes of impiety and disbelief. We know that Ficino himself was a melancholic who believed himself to be under the influence of Saturn, and it is likely that he had had early in life a period of disbelief in religion, perhaps under the influence of Lucretius and pagan versions of Plato, and that he later recovered his commitment to Christianity. ${ }^{53}$ The De vita presents itself as a collection of cures for viri studiosi, ingeniosi and literati whose activity as thinkers makes them suffer from melancholia. Although he follows the famous pseudo-Aristotelian Problems (30.1) in saying that the greatest artists and intellectuals have been melancholics, most of Book I treats black bile and melancholic disease as a monstrum and a pestilentia and is devoted to 
finding ways of obviating its effect on the soul - chiefly through diet, moderate exercise, music, medicines, a harmonious environment, and inhalations and talismans. In Book III he devotes much of his space to magical techniques for maximizing good astrological influences and minimizing bad ones, among them the baleful effects of Saturn on intellectuals. In all three books he emphasizes the importance of spiritus, the fine-material tertium quid that ties together body and soul. Though as a Platonist Ficino believed that the wise man will dominate the stars, sapiens dominabitur astris, that the mind was not under the control of elemental or astral influences, he also believed that even a brilliant mind could be led into unwisdom if its corporeal vehicle existed in an inharmonious and diseased state. The way to restore health and harmony of soul and body was through medicine and magic that operated not just on the body but also on the spiritus.

So the prescriptions and analysis of De vita ought to have been, on Ficinian assumptions, the perfect cure for atheism and religious doubt of all kinds, insofar as these were states of mind supported by bodily disorders. Yet Ficino nowhere says in so many words that his cures are intended for persons afflicted by doubt and irreligious skepticism. He does say that the melancholic humor, if overabundant or too strong, afflicts the mind with continual anxiety and incessant delusions, and deranges the judgement.' Literary men would in fact be particularly sane people if it were not for the fact that the black bile and phlegm of the melancholic forced them (compellantur) to frequent depression and even unwisdom (desipere). ${ }^{54}$ Elsewhere he quotes Plato to the effect that ingeniosi are subject to agitation and madness. ${ }^{55}$ At both the beginning and the end of Book I, quoting Plato, he reminds his readers that a healthy soul is also indispensable to a healthy body, and that for this one needs Christ far more than Socrates. ${ }^{56}$ There are a number of other passages of similar import but no express declaration that his medical and magical techniques are useful to fight atheism.

The reason why Ficino does not mention this aim, one may hypothesize, is that he believed his book, addressed as it was to the needs of literati, would come into the hands of many persons who were already atheists or inclined towards impiety. If that were the case, they would resist any attempts to be cured of their affliction once they learned that the book was intended for that purpose. They were presumably indocibiles in the technical sense that word acquired in Ficino's pedagogy, skeptics and sophists who thought they already knew the answers. ${ }^{57}$ But if they were melancholics and Saturnians suffering from the other malignancies associated with those conditions, they might be induced to read Ficino's book 
and apply its remedies if they believed it was intended simply as a guide to health. This hypothesis receives some color from a remark Ficino makes in the Apology at the end of the De vita, addressed to three of his closest disciples:

\footnotetext{
You know, I think, that I have written a book, On Life, divided into three little books. The first book will be entitled On a Healthy Life, the second, On a Long Life, and the third, On Life from the Heavens. The title will act as a pleasant bait, then, and will attract as many as possible to taste of it; but in such a great number, a good many will be ignorant, as I think, and not a few malicious as well. ${ }^{58}$
}

The word 'bait' (esca) alerts us to what is probably going on in the case of De vita. Ficino was almost obsessed with what he took to be a major fault with the pedagogy of his time, i.e., its tendency to follow a perverse order in presenting philosophical doctrine, with the result that students of philosophy ended up regarding religion as a collection of old-wive's tales. Ficino himself followed what he took to be Socrates's practice: refuting the indocibiles with the hope of rendering them docibiles through the elenchus; then using moral suasion and dialectic on the docibiles; then finally revealing the inner secrets of philosophy only to mature disciples who were already morally pure and throughly educated in advanced logic and the sciences. There was also a gentler way of dealing with the indocibiles, which was to attract them to doctrines they might otherwise find repulsive by means of jokes and verbal play, fables, poetry, and practical knowledge:

Our Plato, in the midst of treating, often in a hidden manner, the necessary duty of the human race, from time to time seems to joke and play. But Platonic jokes and games are much more serious than the serious discourse of the Stoics. For he does not disdain to wander anywhere through more humble things so long as he can insensibly captivate his humbler listeners and lead them more easily to the sublime. Often-for very serious reasons-he will mix the useful and the sweet, so that by his gentle wit and seductive talk he may use the bait (esca) of pleasure to entice minds naturally prone to pleasure to take solid food. 59

So one explanation that would save the phenomena is that Ficino is concealing for tactical reasons his hope that De vita will act as a bait to lure religious melancholics into a sound regimen, and that this will in turn strengthen their bodies and spirits to the point where they 
can return to health and true religion. If melancholy, as Burton declared, was the devil's bait, sound medicine, Ficino must have thought, was the bait of God.

\section{NOTES}

1 This article was written at the Institute for Advanced Study, Princeton, to which I should like to express my gratitude. I am especially grateful to Jonathan Israel and Heinrich von Staden for their invaluable advice on the history of atheism and medicine respectively and for a number of useful references.

2 The Anatomy of Melancholy, Part 3, Section 4, Membrum 1, Subsect 1 (herafter cited by number only, e.g., 3.4.1.1): 'I have no patterne to followe as in some of the rest, no man to imitate. No Physitian hath as yet distinctly written of it [religious melancholy] as of the other [love melancholy], all acknowledge it a most notable Symptome, some a cause, but few a species or kinde' (p. 330). All quotations are from volume 3 of the Clarendon edition of Burton's Anatomy of Melancholy, ed. J. B. Bamborough, et al., 6 volumes (Oxford:

Clarendon Press, 1989); the page numbers cited are from this edition. Bamborough's commentary on Part 3 , Section 4 is in volume 6.

${ }^{3}$ Burton, Anatomy, 3.4.1.1, pp. 337-38.

4 Burton, Anatomy, 3.4.1.1, p. 338.

${ }^{5}$ Burton, Anatomy, 3.4.2.1, p. 395. The reference is to Melanchthon, De anima (1603), p. 359, according to Bamborough's commentary in the Clarendon edition (6:261). It is interesting, if not necessarily a proof of direct influence, that Ficino too describes the melancholy humor leading to religious doubt as monstruosum; see Platonic Theology 14.10.6. All references to the latter are to the book, chapter and paragraph divisions in Marsilio Ficino, Platonic Theology, ed. and tr. Michael J. B. Allen and James Hankins, 6 vols. (Cambridge, MA: Harvard University Press, 2001-2006). All translations are by Allen unless otherwise noted.

${ }^{6}$ The Sadducees are probably included because the New Testament (Matthew 22:29-32) presents them as a sect of Jews who denied the immortality of the soul.

${ }^{7}$ Burton, Anatomy, 3.4.2.1, p. 401.

8 'Galenists' are presumably included here owing to Galen's reputation for offering a somaticist view of the soul, hence denying its immortality: see Vivian Nutton, 'De placitis Hippocratis et Platonis in the Renaissance', in Le opere psicologiche di Galeno. Atti del Terzo Colloquio Galenico Internazionale, Pavia, 10-12 settembre 1986, ed. P. Manuli and M. Vegetti (Naples: Bibliopolis, 1988), pp. 281-309, at 284-285.

${ }^{9}$ Burton, Anatomy, 3.4.2.1, p. 399.

${ }^{10} \mathrm{It}$ is sometimes asserted that Burton was the first to use the term 'deist' in English, but it should be noted that in his usage it applies to hard philosophical atheists (p. 400) and not to religious relativists or doctrinal minimalists. The latter position Burton assimilates to that of skeptics like Cicero and Sextus Empiricus, or to the Neoplatonic philosopher Porphyry, who is lumped with the soft atheists because of his opposition to Christian exclusivism. His use of the word follows that of Marin Mersenne, whose Quaestiones celeberrimae in Genesim (Paris, 1623) — which despite the title is devoted to attacking atheism-Burton cites frequently. In L'impieté des deistes athées, et libertins de ce temps (Paris, 1624), f. ii $r$ - $v$, Mersenne distinguishes between the traditional term 'atheist' and the new term 'deist', which, he says, is simply a cloak borrowed by 'les complices de ceste faction [...] pour abuser les ames plus simples et credules par l'opinion qu'ils leur donnent de recognoistre un Dieu.' In other words it is a euphemism for atheism invented by contemporary atheists to conceal their impiety.

11 See Jonathan I. Israel, Enlightenment Contested: Philosophy, Modernity, and the Emancipation of Man, 1670-1752 (New York: Oxford University Press, 2006), pp. 164-175.

12 See I Samuel 16:14-23. Saul's evil humor was relieved by David's playing on the harp, providing Scriptural justification for the physiological approach to altering mental states.

${ }_{13}$ Burton, Anatomy, 3.4.2.3, p. 411. See also the parallel passage at 3.4.2.6, p. 433.

14 Burton, Anatomy, 3.4.2.6, pp. 442-43.

15 Burton, Anatomy, 3.4.2.6, pp. 424-25.

${ }^{16}$ See J. B. Bamborough, 'Burton and Hemingius', Review of English Studies, n.s. 34, no. 136 (November, 1983): 441-45, and the Clarendon edition of Burton, 6: 281.

${ }^{17}$ Burton, Anatomy, 3.4.2.6, p. 443. 
${ }^{18}$ On Burton's sources for religious melancholy see Michael Heyd, 'Robert Burton's Sources on Enthusiasm and Melancholy: From a Medical Tradition to Religious Controversy', History of European Ideas 5.1 (1984): 17-44. Heyd examines only the sources for the excess of religious melancholy, i.e., enthusiasm. There is no similar study for its defect—despair, impiety and atheism—but J. B. Bamborough's commentary in vol. 6 of the Clarendon edition is an invaluable guide to Burton's sources. A recent study of Burton's context with full bibliographies is Angus Gowland, The Worlds of Renaissance Melancholy: Robert Burton in Context (Cambridge: Cambridge University Press, 2006), which I have not been able to consult.

${ }^{19}$ The connection of melancholy with psychic states such as anguish, sadness, misanthropy, paranoia, suicidal tendencies, and frightening dreams and visions in general is of course deeply rooted in the ancient tradition of melancholy. See the fundamental studies of this tradition in Raymond Klibansky, Erwin Panofsky and Fritz Saxl, Saturn and Melancholy: Studies in the History of Natural Philosophy (New York: Basic Books, 1964), and Jackie Pigeaud, Les maladies de l'âme: Étude sur la relation de l'âme et du corps dans la tradition médico-philosophique antique (Paris: Les Belles Lettres, 1989). For another passage not discussed by Klibansky et al., see the Commentary on the Timaeus in Ficino's Opera Omnia (Basel: Heinrich Petri, 1576; reprinted Turin: Bottega d'Erasmo, 1959; reprinted Paris: Phénix Editions, 1999), 2, pp. 1465, 1483.

${ }^{20}$ See H. J. Blumenthal, Plotinus' Psychology: His Doctrines of the Embedded Soul (The Hague: Martinus Nijhof, 1971), esp. p. $15 f$.

${ }^{21}$ See Platonic Theology 1.3-4, obviously dependent on Plotinus, Enneads 4.2. See also his commentary on the Timaeus (Ficino, Opera 2, p. 1464 f.), where Plotinus's image-soul as divided in the body is assimilated to Aristotle's irrational soul (perhaps following Plotinus himself at Enneads 5.9.6): 'Irrationalem vero animam Platonici non tam substantiale aliquid quam accidentale quiddam esse putant, quasi rationalium vestigium (animarum, in quo sensus quidem sint, sed per diversa corporis instrumenta divisi atque patibiles.... Irrationalem vero in membris quodammodo residere, et partem quidem eius audaciae et iracundiae compotem cordi, partem vero concupiscentiae deditam iecorii commodatam.' In Ficino, Opera 2, p. 1477, Ficino calls the

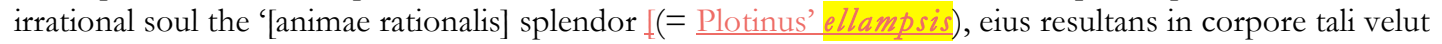
speculo, qui sane splendor dependet ex anima nostra ferme, velut ex luna, et ab anima sphaerae, quasi sole, virtus quidem rationalis manifestius officium suum exercet in capite, irrascibilis in corde, concupiscibilis in iecore.'

${ }^{22}$ Timaeus 43a-44a. Ficino comments on this passage in his Commentary on the Timaeus (Opera 2, p. 1471). See also the important passage at 86b-87a, where Plato says that folly and stupidity are diseases of the soul in part caused by excessive pleasures and pains and even by 'a faulty habit of the body' (Ficino's comments are at ibid., 2, p. 1465). Other important passages can be found passim in the Phaedo, where Socrates speaks of the body 'contaminating' the soul with its presence, 'filling it with lusts', 'bewitching it with passions and pleasures'.

${ }^{23}$ Marsilio Ficino, Three Books on Life, ed. Carol V. Kaske and John R. Clark (Binghamton, NY: Medieval and Renaissance Texts and Studies and the Renaissance Society of America, 1989, p. 102 (but my translation).

${ }^{24}$ On Ficino's Galenism, see Nutton, 'De placitis', pp. 292-93.

${ }^{25}$ Luis Garcia Ballester, 'Soul and Body: Disease of the Soul and Disease of the Body in Galen's Medical Thought', in Le opere psicologiche, pp. 117-150; Heinrich von Staden, 'Body, Soul, and Nerves: Epicurus, Herophilus, Erasistratus, the Stoics, and Galen', in Psyche and Soma: Physicians and Metaphysicians on the Mind-Body Problem from Antiquity to Enlightenment, ed. J. P. Wright and P. Potter (Oxford: Clarendon Press, 2000), pp. 79116, esp. 105-116.

${ }^{26}$ Ibid., p. 106.

${ }^{27}$ See Ballester, 'Soul and Body', p. 143 for an exception. For Platonic psychotherapy see P. Laín Entralgo, 'La razionalización platónica del ensalmo y la invención de la psicoterapia verbal', Archivos Iberoamericanons de Historia de la Medicina, 9 (1957): 133-60; idem, La curación por la palabra en la antigúedad clásica (Barcelona: Anthropos, 1987), pp. 199-241.

${ }_{28}$ The classic works are Klibansky, et al., Saturn and Melancholy, and D. P. Walker, Spiritual and Demonic Magic from Ficino to Campanella (London: Warburg Institute, 1958; reprint Notre Dame, IN: University of Notre Dame Press, 1975 and Stroud: Sutton Publishing Limited, 2000).

${ }^{29}$ A preliminary sketch was presented in James Hankins, 'Religion and the Modernity of Renaissance Humanism', in Interpretations of Renaissance Humanism, ed. Angelo Mazzocco (Leiden: E. J. Brill, 2006), pp. 137153.

${ }^{30}$ In the introduction to Kaske and Clark, eds. Three Books on Life, p. 24; on the other hand, it is said that Burton's Ficino was the Ficino of De vita and De amore; this view is borne out by the index of sources to the 1989 Clarendon edition (vol. 6, p. 348), which shows that most of Burton's citations are from Ficino's De vita 
and his Plato commentaries. The Platonic Theology is not identified as a source, though indirect or otherwise unacknowledged use is by no means out of the question

31 See my analysis of the work's tripartite structure in Platonic Theology, ed. and tr. Allen and Hankins, vol. 6, pp. 319-326.

32 See Wolfgang B. Fleischmann, 'Lucretius', in Catalogus Translationum et Commentariorum: Medieval and Renaissance Latin Translations and Commentaries, Annotated Lists and Guides, ed. P. O. Kristeller and F. E. Cranz (Washington, D.C.: The Catholic University of America Press, 1971), pp. 349-367.

${ }^{33}$ Alison M. Brown, 'Lucretius and the Epicureans in the Social and Political Context of Renaissance Florence', I Tatti Studies, 9 (2001), pp. 11-62; eadem, 'Reinterpreting Renaissance Humanism: Marcello Adriani and the Recovery of Lucretius', in Mazzocco, Interpretations, pp. 267-291. In the generation after Ficino, Brown identifies three Lucretians, Marcello Adriani, Raffaele Franceschi and Machiavelli. The first two were professors of literature at the Florentine Studio and students of Poliziano. The reading of Lucretius was prohibited in Florentine schools in 1517. The thinker who seems to have come closest to the Epicurean critique of religion in Ficino's time was Filippo Buonaccorsi (Callimachus Experiens), on whom see Cesare Vasoli, Tra "maestri" umanisti e teologi: Studi quattrocenteschi (Florence: Le Lettere, 1991), pp. 142-72.

${ }^{34}$ James Hankins, Plato in the Italian Renaissance, 2 vols. (Leiden: E. J. Brill, 1990), 2, pp. 456-58. ${ }^{35}$ James Hankins, Plato in the Italian Renaissance, 2 vols. (Leiden: E. J. Brill, 1990), 2, pp. 456-58.

36 James Hankins, 'Ficino's Theology and the Critique of Lucretius', forthcoming in the proceedings of the conference Platonic Theology: Ancient, Medieval and Renaissance, held at the Villa I Tatti and the Istituto Nazionale di Studi sul Rinascimento, Florence, 26-27 April 2007.

${ }^{37}$ Platonic Theology 1.1 and De christiana religione, cap. I (Opera, 1: 2).

${ }^{38} \mathrm{Ibid}$. See also PT 1.1.1.

${ }^{39}$ Platonic Theology 14.9.1. Or $a$ true religion: the Latin is ambiguous, perhaps intentionally. Needless to say, the argument is formally invalid. Michael Allen's translation of 'Est igitur vera religio' is 'Religion therefore is true'. 40 Platonic Theology, 1.1.1.

${ }^{41}$ Platonic Theology, 14.9.2.

42 'Marsilio Ficino on Reminiscentia and the Transmigration of Souls' Rinascimento, n.s. 45 (2006), 3-17.

43 14.10.8: 'Neque silentio praetereundum puto maximam impietatis causam a Platonicis in genus infimorum daemonum referri solere, qui tacita quadam persuasione vel propter ambitionem in falsam vel propter invidiam in nullam religionem pro viribus nos impellunt.' 'Nor should we pass over in silence, I think, the fact that the Platonists customarily refer the chief cause of impiety to the race of the lowest demons who use all their power and mute persuasion to impel us either by way of ambition towards [a] false religion or by way of envy towards no religion at all.'

${ }^{44}$ 14.10.6: 'Quod autem in pluribus perfectioribusque est, naturale censetur. Quod in paucissimis et aegrotantibus, monstruosum. At vero naturale quidem veridicum, monstruosum vero fallax esse solet.'

45 Cit. Proclus, In Timaeum 1.208.17-23 (ed. Diehl).

46 Platonic Theology, 14.10.2.

${ }^{47}$ Discussed at length in Hankins, 'Religion and the Modernity of Renaissance Humanism' (see n. 22 above).

${ }^{48}$ In part dependent on the locus classicus of Ficino's theory of melancholy, Pseudo-Aristotle, Problemata 30, 1, and Cicero, Tusculan Disputations 1.33.80.

49 Platonic Theology, 14.10.5.

${ }^{50}$ Platonic Theology, 14.10.5. On the baleful influence of Saturn the classic work remains Klibansky et al, Saturn and Melancholy. Ficino was comforted to learn from Firmicus Maternus that Plato, in addition to being a

melancholic, was also of Saturnine character: see ibid., p. 261 and Kaske and Clarke, eds., Tbree Books on Life, p. 22.

${ }^{51}$ Platonic Theology, 14.10.6.

52 Platonic Theology, 14.10.7.

${ }^{53}$ See above, note 26. For Ficino's own melancholy and Saturnine temperament, see the evidence assembled by Kaske and Clark in the introduction to their edition of De vita, pp. 19-22.

${ }^{54}$ Ibid. p. 112 (but my translation).

55 Ibid. p. 117.

${ }^{56}$ Ibid. pp. 107, 161.

${ }^{57}$ Hankins, Plato, p. 331.

${ }^{58}$ Ed. Kaske and Clark, pp. 394-95.

${ }^{59}$ Ficino, Opera, 2, p.1129. For Ficino's pedagogy in general see Hankins, Plato, vol. 1, pp. 296-300, 328-335. 